University of Nebraska - Lincoln

DigitalCommons@University of Nebraska - Lincoln

Agronomy \& Horticulture - Faculty Publications

Agronomy and Horticulture Department

2014

\title{
Evaluation of Soilless Media Sensors for Managing Winter-time Greenhouse Strawberry Production using a CapMat System
}

\author{
George E. Meyer \\ University of Nebraska-Lincoln, gmeyer1@unl.edu \\ Ellen T. Paparozzi \\ University of Nebraska-Lincoln, etp1@unl.edu \\ Stacy A. Adams \\ University of Nebraska-Lincoln, sadams1@unl.edu \\ Diego Scacalossi Voltan \\ Sao Paulo State University
}

Follow this and additional works at: https://digitalcommons.unl.edu/agronomyfacpub

Part of the Agricultural Science Commons, Agriculture Commons, Agronomy and Crop Sciences Commons, Botany Commons, Horticulture Commons, Other Plant Sciences Commons, and the Plant Biology Commons

Meyer, George E.; Paparozzi, Ellen T.; Adams, Stacy A.; and Voltan, Diego Scacalossi, "Evaluation of Soilless Media Sensors for Managing Winter-time Greenhouse Strawberry Production using a CapMat System" (2014). Agronomy \& Horticulture -- Faculty Publications. 1110.

https://digitalcommons.unl.edu/agronomyfacpub/1110

This Article is brought to you for free and open access by the Agronomy and Horticulture Department at DigitalCommons@University of Nebraska - Lincoln. It has been accepted for inclusion in Agronomy \& Horticulture -Faculty Publications by an authorized administrator of DigitalCommons@University of Nebraska - Lincoln. 


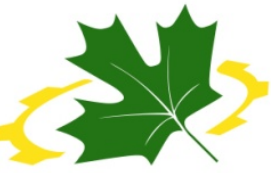

CSBE $\mid$ SCGAB
An ASABE - CSBE/ASABE Joint Meeting Presentation

Paper Number: 141913441

\title{
Evaluation of Soilless Media Sensors for Managing Winter-time Greenhouse Strawberry Production using a CapMat System
}

\author{
George E. Meyer \\ Biological Systems Engineering \\ Ellen T. Paparozzi \\ Agronomy and Horticulture \\ Stacy A. Adams \\ Agronomy and Horticulture \\ University of Nebraska, Lincoln, NE \\ Diego Scacalossi Voltan \\ Visiting PhD Student \\ São Paulo State University, Botucatu -SP, Brazil \\ Written for presentation at the \\ 2014 ASABE and CSBE/SCGAB Annual International Meeting \\ Sponsored by ASABE \\ Montreal, Quebec Canada
}

July $13-16,2014$

\begin{abstract}
It is important for a greenhouse strawberry grower to know that their capillary mat (CapMat ${ }^{\mathrm{TM}}$ ) fertigation system is working correctly and that plants are receiving the correct amounts of water and fertilizer. Pots with soilless mix are not expected to hold more than $70 \%$ water on a volumetric basis. Pots with less than $40 \%$ water content continuously are not supplied enough water and nutrients to the plants. Typically, pots located near the manifold distribution system get a little more water than those at the other locations, but water use will really vary according to the factors listed above as well as environmental parameters, but should not vary more than $20 \%$. Fertigation is based on the drip tape distribution system, the media density of individual pots, and the spatial energy distribution within the greenhouse. To understand how these factors interact, pot moisture, media temperature, and electrical conductivity were spot checked with a relatively new commercial sensor and also monitored continuously along with greenhouse temperature, humidity, and photosynthetically active radiation (PAR) using a data logger system. We found that the variance in pot medium moisture and fertilizer was as expected as were fluctuations in air and mix temperatures. Calibrated commercial electrical conductivity and soil moisture sensors for measuring pot moisture and/or electric conductivity were reliable. Having this data may be a key to determining why plants in the UNL greenhouse produced more marketable fruit than plants in the commercial house.
\end{abstract}

Keywords: Greenhouses, Instrumentation, Photosynthetically Active Radiation, capillary mats, strawberry production.

The authors are solely responsible for the content of this meeting presentation. The presentation does not necessarily reflect the official position of the American Society of Agricultural and Biological Engineers (ASABE), and its printing and distribution does not constitute an endorsement of views which may be expressed. Meeting presentations are not subject to the formal peer review process by ASABE editorial committees; therefore, they are not to be presented as refereed publications. Citation of this work should state that it is from an ASABE meeting paper. EXAMPLE: Author's Last Name, Initials. 2014. Title of Presentation. ASABE Paper No. ---. St. Joseph, Mich.: ASABE. For information about securing permission to reprint or reproduce a meeting presentation, please contact ASABE at rutter@asabe.org or 269-932-7004 (2950 Niles Road, St. Joseph, Ml 49085-9659 USA).

\section{Introduction}


Nebraska is known nationally for agricultural crop production, producing more than 1.6 billion bushels of corn and 253 million bushels of soybeans alone in 2013 (Nebraska Department of Agriculture, 2014 Ag Facts). In addition, Nebraska is one of the top three edible dry bean, popcorn and millet producers in the nation. This success is due to abundant sunshine, warm temperatures and plentiful moisture during the May through October growing season. However, what is not well known is that some of the sunniest days of the year occur during the winter months.

Given the extensive amount of solar energy available during the winter months, it has yet to be exploited and turned into an additional food production opportunity in Nebraska. Through the use of season extension tools, such as greenhouses and high tunnels, a potential exists for farmers to acquire an additional source of income to complement their usual field season. Research by Hoagland, et al (2008) found that the average corn/soybean farmer has sufficient labor and/or time available during December through March in which could be utilized to grow alternate crops.

There is a strong desire by the consumer for high quality, locally produced fruits, herbs and vegetables that are now only available on a seasonal basis. Through the use of season extension tools and equipment, having optimal amount of solar radiation throughout the year, and the availability of a seasonal labor force, research of additional specialty crops should be explored. The challenge to winter production of fruit and vegetable crops in Nebraska is outdoor temperatures, which may be moderate to severe from one year to the next. Greenhouse producers in this region may utilize as much as $60 \%$ of their budget towards heating alone, indicating that sustainable methods that reduce this cost are needed for increased profits.

The overall goal of a new five-year Multistate 1335 contribution is to enhance Nebraska's economy by growing high 'value' horticultural crops during the winter months. NE1335 project members have identified five high priority greenhouse topics to address over the next 5 years. They are (1) energy conservation and alternative energy sources (Mabie et al, 2009, 2013), (2) water and nutrient solution management (Garland, et al, 2012, Liu, et al, 2012), (3) sensors and control systems, (4) environmental and ecological effects on plant production, and (5) improved ventilation design and heat-loss control. Nebraska's contribution will particularly focus on topics (1), (2), and (3).

Strawberries are one crop that could potentially be produced by a farmer during their "off season" as an additional income source. Strawberry production during the winter time has occurred in warmer climates and even greenhouses in those climates (Paranjpe, et al, 2003). Production in west central Florida occurs typically during February, March, and April. Strawberries have been propagated in greenhouses in Europe for many years (Durner, 1999). Hancock (2000) presented factors and conditions for growing strawberries. Paparozzi (2013) discussed the major issues for growing winter time strawberries in greenhouses in Nebraska. An important question has initially arisen for growing strawberry plants in greenhouses: is there adequate light available during the winter months for successful flower and fruit production in Nebraska?

Incoming solar energy in greenhouses is partitioned between diffuse (major component on cloudy days) and direct beam (primary component on clear days). Incident direct beam radiation depends on the changing solar altitude and azimuth angles of the sun during the day. Radiant energy incident on greenhouse plants is received from the incoming solar radiation (sky direct and diffuse) and indirectly received from radiation reflected off physical surfaces within the vicinity of the plants. Incident solar radiation available for plant growth is reduced by the optical transmittance of the greenhouse glazing, but may retain some directionality, making some parts of the greenhouse bench brighter than others. The estimated amount of incident light useful for plant growth is reported as Photosynthetically Active Radiation (PAR) or photon flux density (PPFD, $\mu$ moles $\mathrm{m}^{-2}$ $\mathrm{s}^{-1}$ ). The actual amount of short wave energy intercepted by plants is also related to canopy architecture and plant population. Ideally, a plant fully bathed in PAR (top and bottom leaves) will be a productive plant (Meyer, et al 2012). 


\section{Objectives $^{1}$}

1. To compare water and nutrient guidelines for a commercial heated high tunnel house (hybrid) versus a UNL campus double polyethylene greenhouse for production of strawberries under winter-time conditions.

2. To compare climatic, production, and operational differences of the two houses indicated in Objective 1.

\section{Procedures and Methods}

To accomplish these objectives, a study was undertaken in eastern Nebraska using a typical and existing Quonset, double polyethylene commercial style production greenhouse design. A university greenhouse (ENT3 ) was used on the University of Nebraska East Campus (Figure 1). The dimensions of ENT-3 were $20 \times 84 \times$ $10 \mathrm{ft}$. at the peak $(6 \times 25.5 \times 3 \mathrm{~m})$. A second double poly house was constructed at Dwight Nebraska (Figure 2). The dimensions of the commercial cooperator's heated high tunnel were $26 \times 72 \times 12 \mathrm{ft}$. at the peak $(7.9 \times 22 \times$ $3.6 \mathrm{~m}$ ) with $5 \mathrm{ft}$. (1.52 m) sidewalls. Each house featured simple, clear-span construction, a commercial natural gas or propane-fired heat source, hand-constructed benches, improved night-time insulation techniques, improved immersion of plants onto light \{photosynthetically-active-radiation (PAR)\} using a white plastic reflective mulch, and an automatic, efficient watering/fertigation system using a capillary mat system (CapMat $\mathrm{II}^{\mathrm{TM}}$, Phytotronics, Inc., Earth City, MO USA). One major difference of the heating systems for the two houses was that the fan-tube distribution system was located under the benches in ENT-3. Distribution fans were used in the cooperator house in the absence of a fan-tube system.

Both research and cooperator houses were fully equipped with low-cost instruments and sensors to automatically monitor temperature, humidity, light quantity, quality, water and fertilizer utilization as well as heating and cooling operations - all aimed towards reducing inputs, but maximizing output. The cooperator greenhouse was outfitted with an IR/AC plastic glazing. This glazing was much clearer than the glazing used on ENT-3, as it was designed with specific resins to allow more infra-red radiation transmission in the PAR region. In addition, this polyethylene incorporated the use of resins that would resist moisture accumulation that causes fogging and increased incidence of condensate drip, both of which will reduce light transmission. However, from previous studies, the IR/AC polyethylene was found to be "softer" because of the additional resins manufactured in the plastic. This resulted in the bubbles emerging from the glazing during harsh winter weather received during 2014. However, condensate accumulation (humidity) and fogging would therefore be more of a problem with the glazing on the campus house.

\section{Fertigation and Soil Sensors}

The capillary mat system was used to water and fertigate a winter strawberry, cultivar, production study for both the UNL East Campus Quonset and the commercial heated high tunnel houses during 2013-2014 (Figure 3). Plants at UNL were grown on two separate $6 \times 20 \mathrm{ft}(1.8 \times 6 \mathrm{~m})$ benches. There were three benches used at the commercial house - two outside benches at $6 \times 65 \mathrm{ft}$. $(1.8 \times 19.8 \mathrm{~m})$ and one center bench at $5 \times 65 \mathrm{ft}$. $(1.52 \times 19.8 \mathrm{~m})$. All of the benches were covered with a single layer of 6 mil, black polyethylene as an initial water and vapor barrier to the floor. CapMat (water absorptive) fabric was installed on top of the black plastic. 4 mil white, polyethylene, top/black bottom (Panda plastic) covered the fabric and had holes cut for each pot (Figure 4). A special jig device was used to install holes to allow individual pots to access the wet fabric through the white polyethylene cover. The latter cover also served as a reflective mulch and vapor barrier to reduce evaporation of moisture to the air. 6-inch, standard pots were set at each mulch hole on the fabric. The CapMat

\footnotetext{
${ }^{1}$ This research was funded in part by grants from the National Sustainable Strawberry Initiative (funded by the Walmart Foundation and administered by the University of Arkansas System Division Of Agriculture Center for Agricultural and Rural Sustainability), Nebraska Department of Agriculture-Horticulture Specialty Block Grant Program, and the USDA/ CSREES Multistate project NE-1035 "Commercial greenhouse production: Components and System". The mention of specific trade names is for reference only and not to the exclusion of other commercial productions. Special thanks and remembrance is given to Mr. Gary Deberg, whose innovations contributing to the Capillary Mat system made this study possible. Special thanks are also given to Mr. Will Denton, undergraduate assistant.
} 
fabric was then wetted using twin wall "seep hose" tubing installed under the white polyethylene and fabric. The concept of the CapMat is to establish a capillary column of water between the fabric and the plant root system. Plant leaves are drier and the whole system is driven by photosynthesis and transpiration. Individual flag pots of strawberries were selected and monitored with new GS3 soil sensors (Decagon Devices, Inc. Pullman, WA) at key entry and downstream locations of the CapMat bench. A commercial soilless mix consisting of peat moss $(50 \%)$, pine bark and perlite with dolomite and started nutrients was used for each pot and a sample was sent to Decagon for GS3 calibration. The soil sensors were installed at three zone locations (north, middle, and south) over the twenty foot length of each bench at the each house.

Liquid water and fertilizer was prepared in a supply tank. An automatic clock controlled valve system moistened and fertigated the CapMats on selected time event schedules. Daily watering event were adjusted during the season and according to crop and environmental conditions to minimize night time humidity levels and to reduce plant disease and pest pressure. An electronic meter was used to measure greenhouse water applied during the growing period. The goal was to adequately water the pots across the bench maintaining a $50-60 \%$ volumetric content. An electronic gas meter was used to monitor natural gas use for ENT-3. Furnace and ventilation events in ENT-3 were controlled by a Groton II system (ACME Engineering and Manufacturing, Inc., Muskogee, OK. The commercial house was heated with propane and the number of gallons of fuel used was also recorded.

The performance of the CapMat II ${ }^{\mathrm{TM}}$ system (Hummert International, St. Louis, MO) had been found to be highly successful during previous strawberry production tests at UNL. This data showed that using this system, pots were provided with uniform and efficient watering/fertigation (Paparozzi, et al, 2011, 2012 a, b, 2013). Figure 5 shows the pot layout and spacing needed to conduct the harvesting of berries.

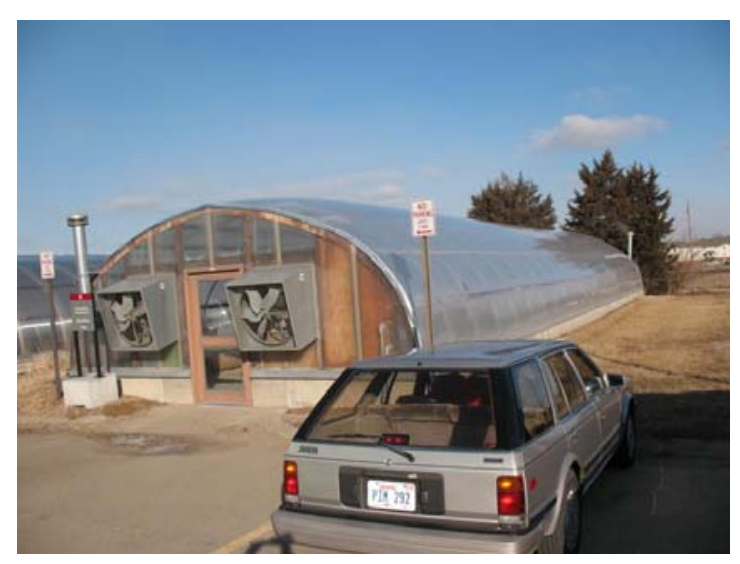

Figure 1. UNL Research Greenhouse (ENT-3).

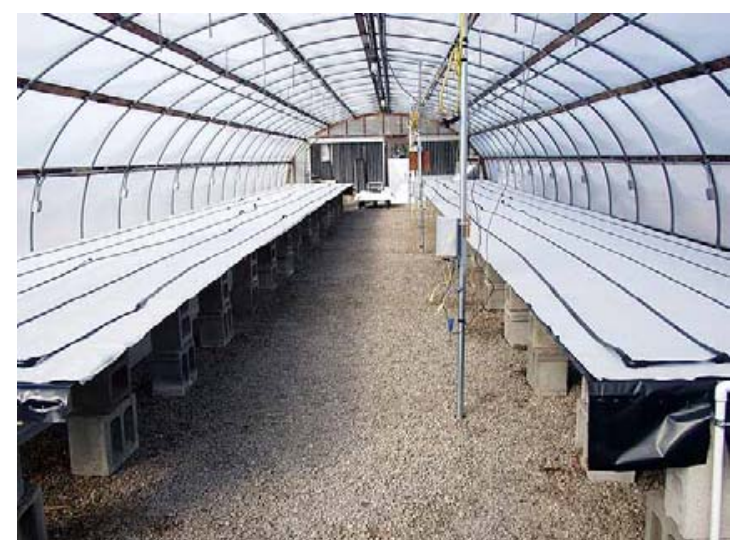

Figure 3. Initial setup of a capillary mat fertigation system. The reflective mulch was placed over the mat and emitters shown (ENT-3).

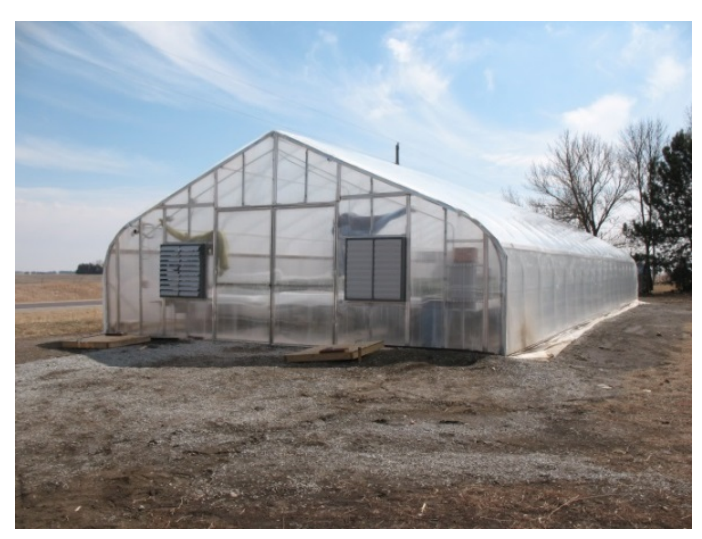

Figure 2. Commercial greenhouse - Dwight, NE.

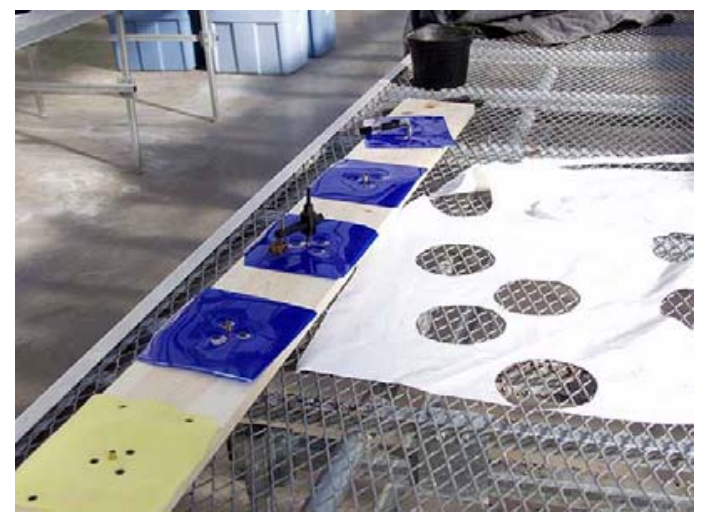

Figure 4. A pot cutter board system for alignment and placement of holes into plastic reflective mulch film for 6-inch pots of strawberries to access Cap Mat irrigation system. (Courtesy of Mr. Gary Deberg, Biological System Engineering Technician). 
Sensors used in the greenhouse project were connected to a Campbell CR 1000 data logger programmed by Loggernet $^{\mathrm{TM}}$ (Campbell Scientific, Inc., Logan, Utah), shown in Figure 6. The soil volumetric water content, media temperature, and electrical conductivity digital sensor and its installation into the root mass are shown in Figures $7 \mathrm{a}, \mathrm{b}$, respectively. A new pH sensor was also tested, but is not reported in this paper.

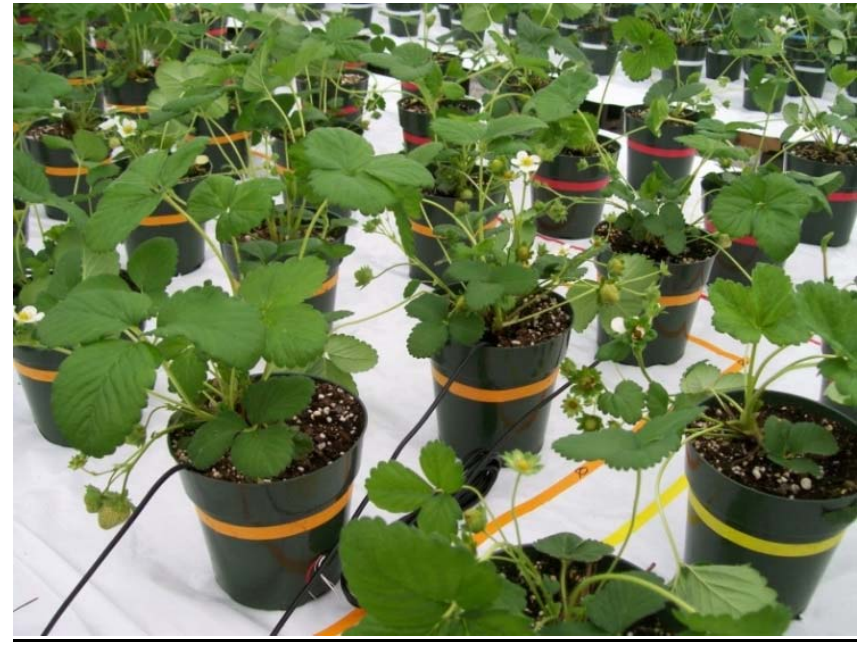

Figure 5. CapMat II with reflective mulch (ENT-3)_and buried sensors.

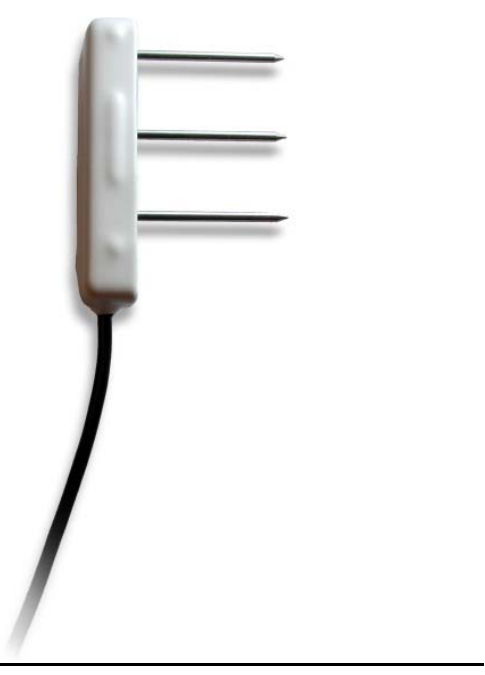

Figure 7a. Decagon GS3 Soil sensor with SDI-12 pigtail.

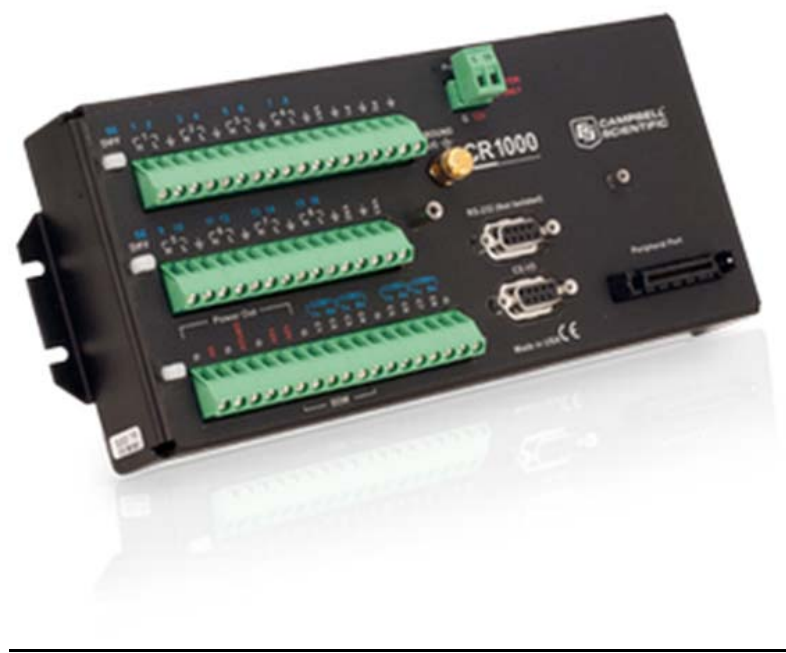

Figure 6. Datalogger (CR 1000 - Courtesy Campbell Scientific).

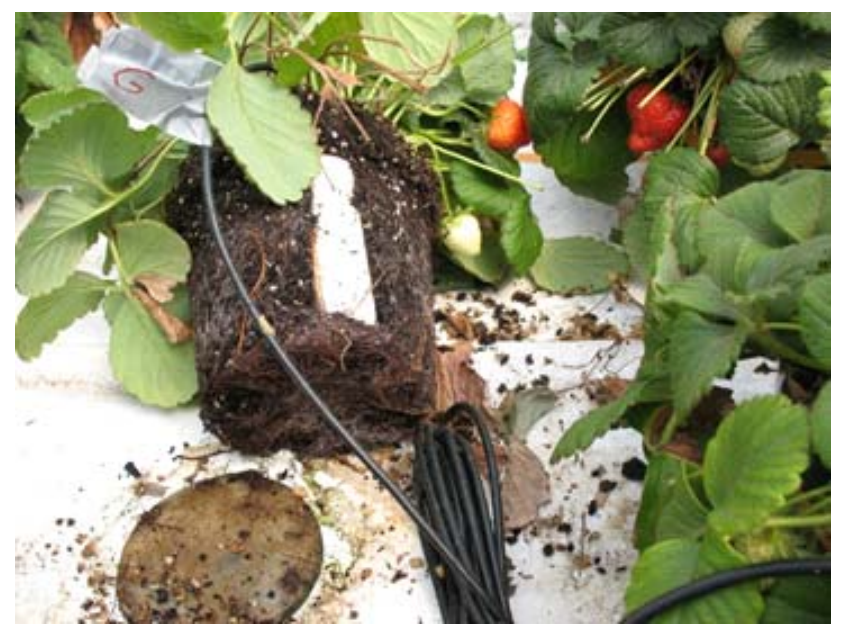

Figure 7b. Decagon GS3 sensor installed vertically across the root mass inside of the pot.

The water content calibration curve for the GS3 is shown in Figure 8. The GS3 sensor also measures the temperature of the soil medium. Sensor placement and spatial distribution was originally studied to determine the minimum number of sensors needed for proper crop management (Burnett, et al, 2012).

\section{Aerial Environment Sensors}

Inside and outside air temperatures and relative humidity were measured using the Campbell CS 215 digital sensor at two locations in ENT-3 and three locations in the cooperator house. Outside temperatures and humidity were measured directly at ENT-3. Additional local climatic data was provided by the High Plains (AWDN) weather Network (Hubbard, et al 1982). The amount of quantum energy (PAR) was measured within each house using LiCor 190 quantum sensors (LiCor, Inc., Lincoln, NE). The LI 190 sensor was crosschecked with a Hydroafarms Basic Quantum meter, Paradigm Gardens, Omaha, NE). All analog and digital 
sensor readings were recorded and averaged every 10-minutes and downloaded weekly for plotting and analysis.

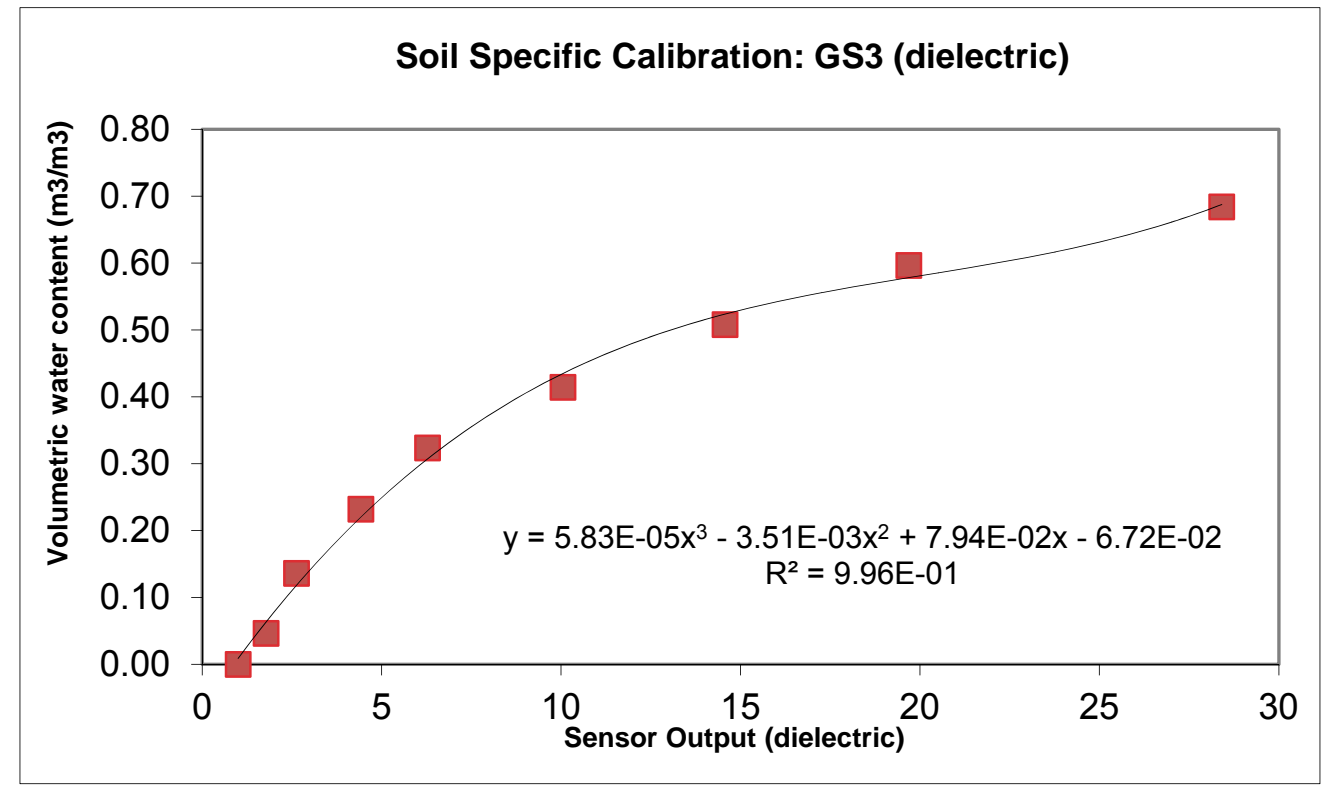

Figure 7. Moisture calibration curve for the strawberry soilless mix using the GS3 soil sensor (courtesy of Decagon, Inc.).

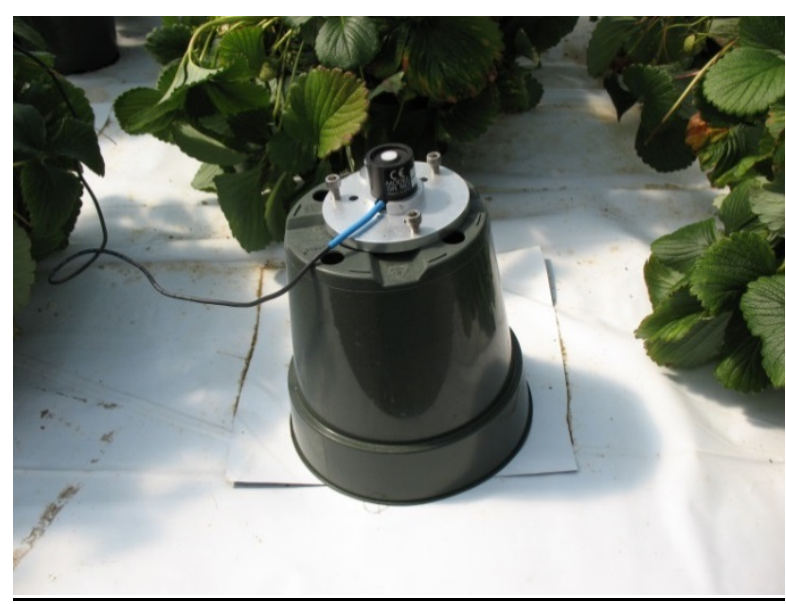

Figure 8. LiCor Quantum Sensor.

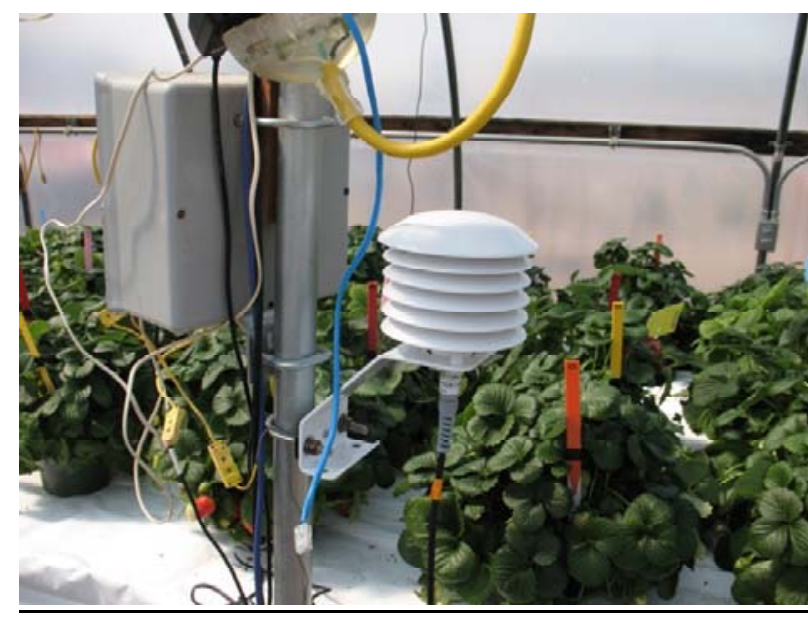

Figure 9.CS215 (SDI-12) Temperature and Humidity Sensor with Radiation shield,

Both the Decagon GS3 and the Campbell Scientific CS215 sensors use the Serial Digital Interface at 1200 Baud (SDI-12) protocol with the Campbell Scientific CR1000 data logger. SDI-12 is a multi-drop interface and can be used to communicate with a number of daisy-chained, multi-parameter sensors. Each sensor is assigned its own unique digital address and each embedded sensor system is queried in sequence by the logger at scheduled intervals. The principle advantage is the use of digital communication which make the sensor system relatively noise free.

\section{Production Activities}

Five strawberry cultivars were grown from October, 2013 through mid-April 2014 and followed a schedule shown in Table 1. The cultivars were: 'Evie-2', 'Evie-2'+, 'San Andreas', 'Seascape', and 'Seascape'+. 
Individual plants were potted in a commercial soilless mix in 6-inch $(15.24 \mathrm{~cm})$ pots and grown on the capillary mats in a double poly greenhouse, located on East Campus, University of Nebraska, Lincoln, NE and at the commercial house in Dwight, NE, as previously described. The UNL experiment was set up as a randomized, complete block design using two benches each with six replications for a total of 12 replications, with up to 48 plants per cultivar. Plants were potted in mid-September and started flowering about 2 weeks later (October 1).

Plant data taken included: date of first flower, total fruit number and berry weight per plant per week. Strawberries were deemed ripe based on a color comparison between berries purchased from a local grocery store and those on the bench. Color was standardized by using the RHS Color Chart (Red Group 46), (Royal Horticulture Society, Surrey, UK). Special greenhouse bumble bees (Bombus impatiens) were introduced when the first flowers began to open. Those data other than final yields are not reported in this paper.

Table 1. Schedule of Strawberry production events.

\begin{tabular}{|c|c|}
\hline March & Ordered dormant strawberry crowns (1 per sq. ft.) - planned on a $10 \%$ loss. \\
\hline June & $\begin{array}{l}\text { Ordered pots, soilless mix, fertilizer ( } 1 \text { bag each at } 20-10-20 \text {, calcium nitrate; } 21-7-7 \text {, bio } \\
\text { fungicide for dipping crowns before planting. }\end{array}$ \\
\hline $\begin{array}{l}\text { September } \\
12-20\end{array}$ & $\begin{array}{l}\text { Crowns were potted; watered un, and placed on wet capillary mats; after } 4 \text { days, starter } \\
\text { fertilizer was applied }(100 \mathrm{ppm} \mathrm{N}(20-10-20) \text { followed by } 100 \mathrm{ppm} \mathrm{N} \text { (calcium nitrate) }\end{array}$ \\
\hline October 1 & $\begin{array}{l}\text { Flowering was observed. Ready for greenhouse bumble bees. Greenhouse air temperatures } \\
\text { were set for } 75^{0} \mathrm{~F}\left(24^{0} \mathrm{C}\right) \text { day/ } 65^{0} \mathrm{~F}\left(18^{0} \mathrm{C}\right) \text { night. Install greenhouse bumble bees. }\end{array}$ \\
\hline October 15 & First berries are harvested. \\
\hline $\begin{array}{l}\text { October 22- } \\
\text { December } \\
15\end{array}$ & $\begin{array}{l}\text { Berry production peaks; stolons removed each week. More bees are ordered as necessary. } \\
\text { Media } \mathrm{pH} \text { is checked. }\end{array}$ \\
\hline $\begin{array}{l}\text { December } \\
15\end{array}$ & $\begin{array}{l}\text { Slowdown in berry production, greenhouse temperatures are dropped to } 70{ }^{0} \mathrm{~F}\left(21^{0} \mathrm{C}\right) \text { day/ } \\
57^{0} \mathrm{~F}\left(14{ }^{\circ} \mathrm{C}\right) \text { night. Media } \mathrm{pH} \text { is checked. }\end{array}$ \\
\hline February 1 & Plants begin to flower again. Added more bees. Media pH is checked. \\
\hline $\begin{array}{l}\text { February 15- } \\
\text { mid April }\end{array}$ & Berries peak in production. Media $\mathrm{pH}$ is checked \\
\hline April & Greenhouse becomes too warm - end of production. \\
\hline
\end{tabular}

\section{RESULTS AND DISCUSSION}

Two quantum transmission studies were conducted for both ENT-3 (March 26, 2014) and the cooperator house (March 28, 2014) around 1:30 PM Central Standard (or near solar noon), as shown in Table 2. Available PAR was based on 20 replications of measurements around the entire outside perimeter of each house (north, south, east, and west) and the averages ranged from 1035 to 1680 micromoles per $\mathrm{cm}^{2}$ per sec. Inside PAR averages for ENT-3 ranged from 796 to 834 micromoles per $\mathrm{cm}^{2}$ per sec. These data were used to calculate an approximate 52-57 percent transmission coefficient for ENT-3. Inside PAR averages for the cooperator house ranged from 1138 to 1272 micromoles per $\mathrm{cm}^{2}$ per sec. An approximate 79-81 percent transmission coefficient was calculated for the cooperator house. Both days were mostly cloud free. However, a number of readings were necessary as the two sites were different due to nearby buildings, trees, and/or parking lots. Simultaneous readings for both the LiCor 190 and the Hydroafarms Basic Quantum meter indicated that each device produced PAR values within \pm 5 percent of each another. It appeared that the IR/AC glazing on the cooperator house was allowing approximately 20 percent more PAR transmission than ENT-3.

Figures 10 and 10b compare weekly average daily PAR values (micromoles per $\mathrm{cm}^{2}$ per sec) for both ENT-3 and the cooperator house during the entire production period, respectively. Averages were more variable for the ENT-3 house than the cooperator house. One of the problems was that sensors were moved around within the strawberry canopies and may have been covered by foliage at times; ENT-3 has a nearby adjacent greenhouse and its shadow could affect late afternoon readings. Overall, it appeared that the cooperator 
house was generally brighter (PAR) during the growth period.

Table 2. Comparison of quantum (PAR) transmissions for the different glazing used on ENT-3 as compared to the new cooperator house.

\begin{tabular}{|c|c|c|}
\hline \multicolumn{3}{|c|}{ ENT-3 } \\
\hline Average Quantum (micromol & les per $\mathrm{cm}^{2}$ per sec) & Average Quantum Transmission - percent \\
\hline West Bench: & 796.4 & \\
\hline East Bench: & 833.6 & \\
\hline Outside Greenhouse" & 1473.3-1533.3 & $52-57$ \\
\hline \multicolumn{3}{|c|}{ Cooperator Greenhouse - Dwight NE } \\
\hline South-West Side: & 1272 & \\
\hline Middle of the House & 1258 & \\
\hline North- East Side & 1138 & \\
\hline Outside Greenhouse: & $1035-1680$ & $79-81$ \\
\hline
\end{tabular}

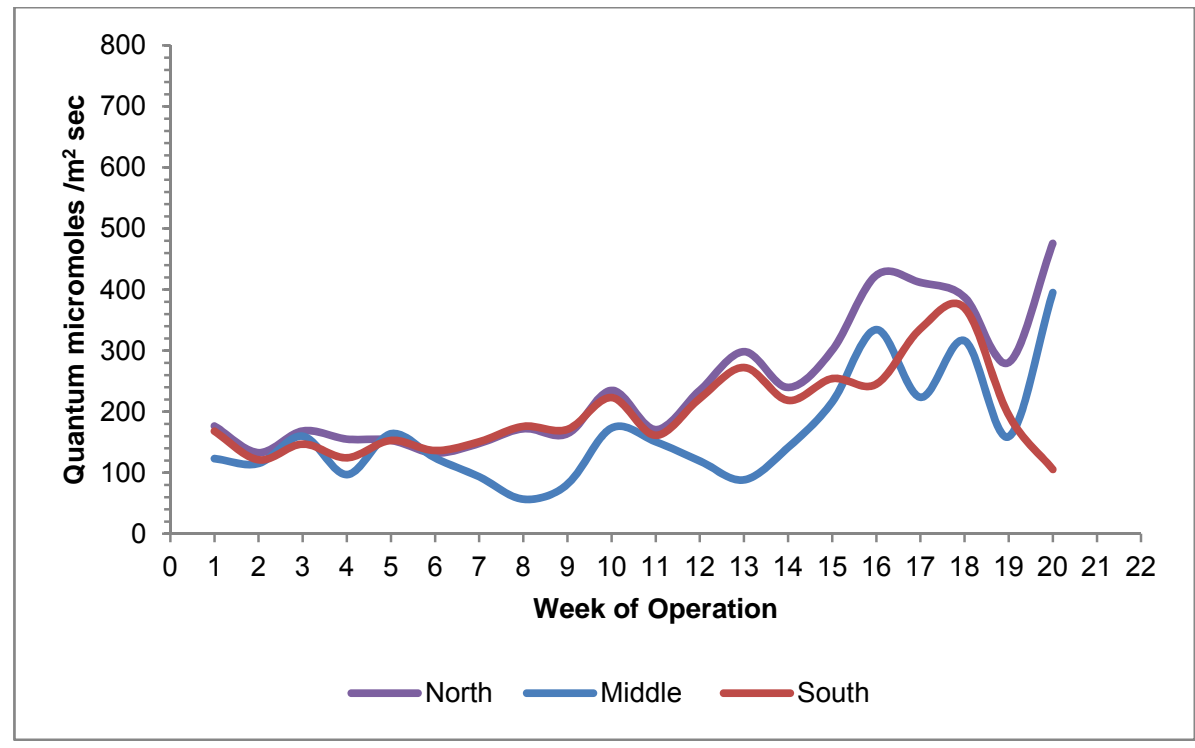

Figure 10a. Average weekly daily quantum radiation (UNL-ENT-3).

\begin{tabular}{|c|c|c|}
\hline Week & \multicolumn{2}{|c|}{ Date Range } \\
\hline 1 & $11 / 25 / 13$ & $12 / 01 / 13$ \\
\hline 2 & $12 / 02 / 13$ & $12 / 08 / 13$ \\
\hline 3 & $12 / 09 / 13$ & $12 / 15 / 13$ \\
\hline 4 & $12 / 16 / 13$ & $12 / 22 / 13$ \\
\hline 5 & $12 / 23 / 13$ & $12 / 29 / 13$ \\
\hline 6 & $12 / 30 / 13$ & $01 / 05 / 14$ \\
\hline 7 & $01 / 06 / 14$ & $01 / 12 / 14$ \\
\hline 8 & $01 / 13 / 14$ & $01 / 19 / 14$ \\
\hline 9 & $01 / 20 / 14$ & $01 / 26 / 14$ \\
\hline 10 & $01 / 27 / 14$ & $02 / 02 / 14$ \\
\hline 11 & $02 / 03 / 14$ & $02 / 09 / 14$ \\
\hline 12 & $02 / 10 / 14$ & $02 / 16 / 14$ \\
\hline 13 & $02 / 17 / 14$ & $02 / 23 / 14$ \\
\hline 14 & $02 / 24 / 14$ & $03 / 02 / 14$ \\
\hline 15 & $03 / 03 / 14$ & $03 / 09 / 14$ \\
\hline 16 & $03 / 10 / 14$ & $03 / 16 / 14$ \\
\hline 17 & $03 / 17 / 14$ & $03 / 23 / 14$ \\
\hline & &
\end{tabular}




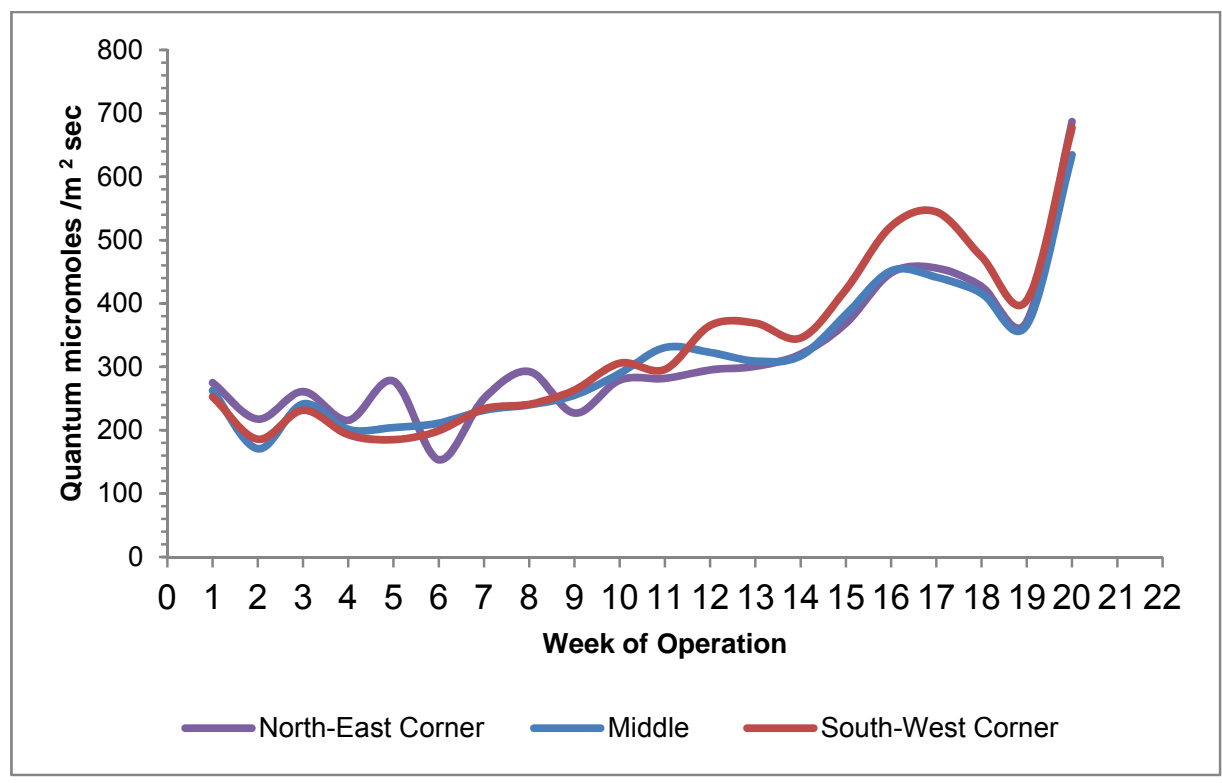

\begin{tabular}{|l|l|l|}
\hline 18 & $03 / 24 / 14$ & $03 / 30 / 14$ \\
\hline 19 & $03 / 31 / 14$ & $04 / 06 / 14$ \\
\hline 20 & $04 / 07 / 14$ & $04 / 13 / 14$ \\
\hline
\end{tabular}

Figure $10 \mathrm{~b}$. Average weekly daily quantum radiations (Commercial Greenhouse).

The comparison of inside air temperatures and relative humidity for both ENT-3 and the cooperator house on a weekly average daily temperature basis are presented in Figures 11 and 12. Diurnal profiles are not shown in these figures. Figure 11a shows that the heating and ventilation system of ENT-3 maintained a consistent and level set of average air temperature from 19 to $22{ }^{\circ} \mathrm{C}$. Outside air temperatures were quite variable, ranging from $-10^{\circ} \mathrm{C}$ to $+10^{\circ} \mathrm{C}$. $2013-2014$ was an extremely cold and windy winter in eastern Nebraska. Inside relative humidity ranged from 48 to 58 percent; while outside humidity was generally 10 percent higher and most of the time over 65 percent (Figure 11b).

In contrast, the cooperator house average air temperatures are shown in Figure 12a and ranged from 15 to 20 ${ }^{\circ} \mathrm{C}$, or about $3-4{ }^{\circ} \mathrm{C}$, cooler than ENT-3. Inside relative humidity ranged from 65 to 80 percent; and most of the time, higher than the outside relative humidity (Figure 12b). Overall, the ENT-3 house was a warmer and drier house than the cooperator house.

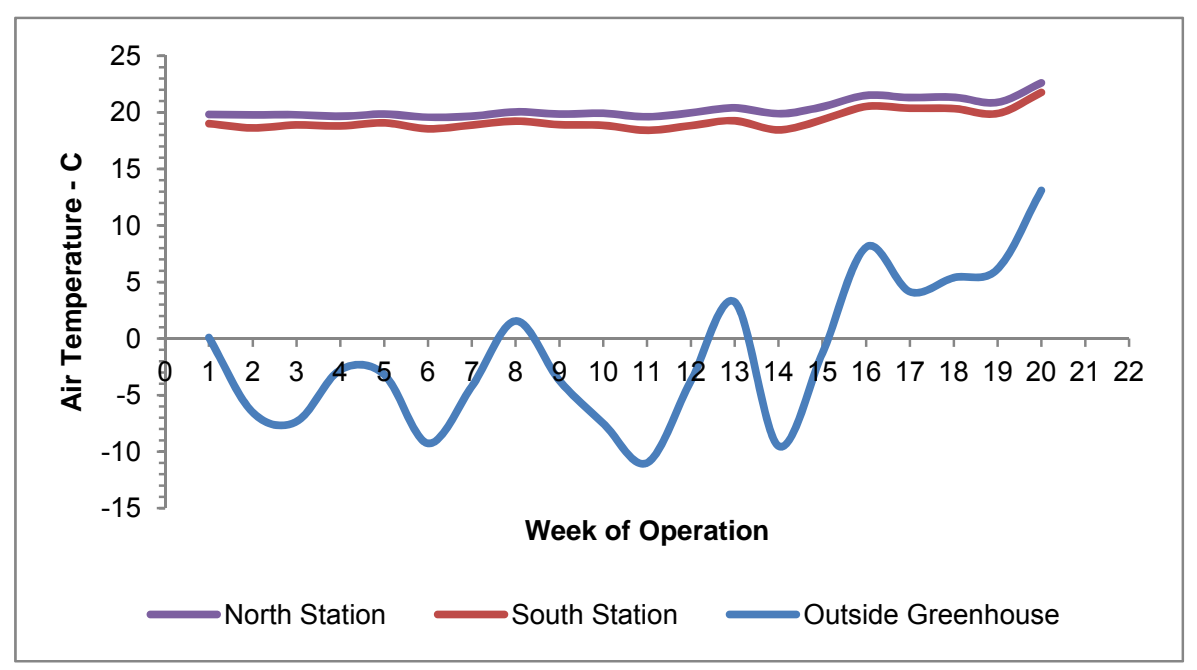

Figure 11a. Average weekly daily air temperature (UNL-ENT-3).

\begin{tabular}{|c|c|c|}
\hline Week & \multicolumn{2}{|c|}{ Date Range } \\
\hline 1 & $11 / 25 / 13$ & $12 / 01 / 13$ \\
\hline 2 & $12 / 02 / 13$ & $12 / 08 / 13$ \\
\hline 3 & $12 / 09 / 13$ & $12 / 15 / 13$ \\
\hline 4 & $12 / 16 / 13$ & $12 / 22 / 13$ \\
\hline 5 & $12 / 23 / 13$ & $12 / 29 / 13$ \\
\hline 6 & $12 / 30 / 13$ & $01 / 05 / 14$ \\
\hline 7 & $01 / 06 / 14$ & $01 / 12 / 14$ \\
\hline 8 & $01 / 13 / 14$ & $01 / 19 / 14$ \\
\hline 9 & $01 / 20 / 14$ & $01 / 26 / 14$ \\
\hline 10 & $01 / 27 / 14$ & $02 / 02 / 14$ \\
\hline 11 & $02 / 03 / 14$ & $02 / 09 / 14$ \\
\hline 12 & $02 / 10 / 14$ & $02 / 16 / 14$ \\
\hline 13 & $02 / 17 / 14$ & $02 / 23 / 14$ \\
\hline 14 & $02 / 24 / 14$ & $03 / 02 / 14$ \\
\hline 15 & $03 / 03 / 14$ & $03 / 09 / 14$ \\
\hline 16 & $03 / 10 / 14$ & $03 / 16 / 14$ \\
\hline 17 & $03 / 17 / 14$ & $03 / 23 / 14$ \\
\hline & & \\
\hline
\end{tabular}




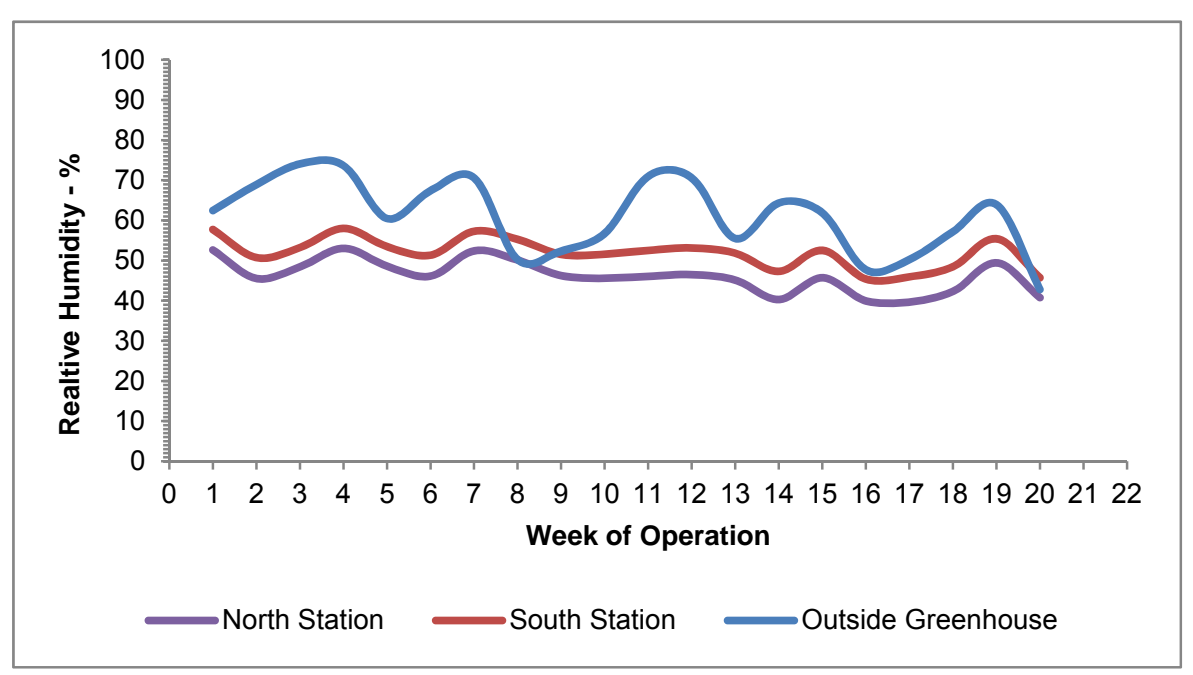

\begin{tabular}{|l|l|l|}
\hline 18 & $03 / 24 / 14$ & $03 / 30 / 14$ \\
\hline 19 & $03 / 31 / 14$ & $04 / 06 / 14$ \\
\hline 20 & $04 / 07 / 14$ & $04 / 13 / 14$ \\
\hline
\end{tabular}

Figure11b. Average weekly Relative Humidity (UNL-ENT-3).

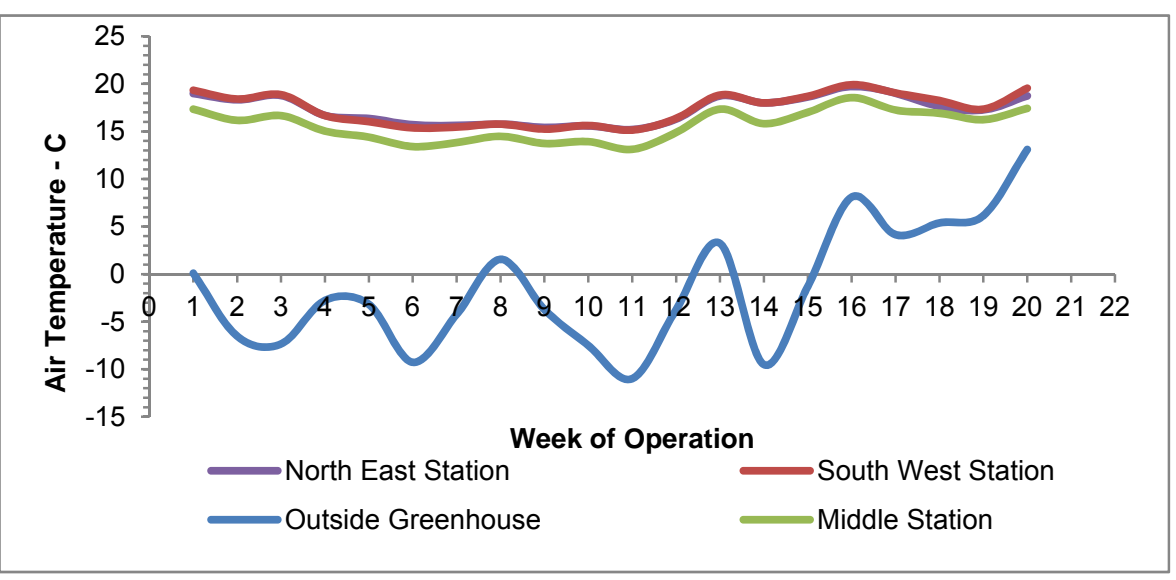

\begin{tabular}{|c|c|c|}
\hline Week & \multicolumn{2}{|c|}{ Date Range } \\
\hline 1 & $11 / 25 / 13$ & $12 / 01 / 13$ \\
\hline 2 & $12 / 02 / 13$ & $12 / 08 / 13$ \\
\hline 3 & $12 / 09 / 13$ & $12 / 15 / 13$ \\
\hline 4 & $12 / 16 / 13$ & $12 / 22 / 13$ \\
\hline 5 & $12 / 23 / 13$ & $12 / 29 / 13$ \\
\hline 6 & $12 / 30 / 13$ & $01 / 05 / 14$ \\
\hline 7 & $01 / 06 / 14$ & $01 / 12 / 14$ \\
\hline 8 & $01 / 13 / 14$ & $01 / 19 / 14$ \\
\hline 9 & $01 / 20 / 14$ & $01 / 26 / 14$ \\
\hline 10 & $01 / 27 / 14$ & $02 / 02 / 14$ \\
\hline 11 & $02 / 03 / 14$ & $02 / 09 / 14$ \\
\hline 12 & $02 / 10 / 14$ & $02 / 16 / 14$ \\
\hline 13 & $02 / 17 / 14$ & $02 / 23 / 14$ \\
\hline 14 & $02 / 24 / 14$ & $03 / 02 / 14$ \\
\hline 15 & $03 / 03 / 14$ & $03 / 09 / 14$ \\
\hline 16 & $03 / 10 / 14$ & $03 / 16 / 14$ \\
\hline 17 & $03 / 17 / 14$ & $03 / 23 / 14$ \\
\hline & &
\end{tabular}

Figure 12a. Average air temperature (Commercial Greenhouse). 


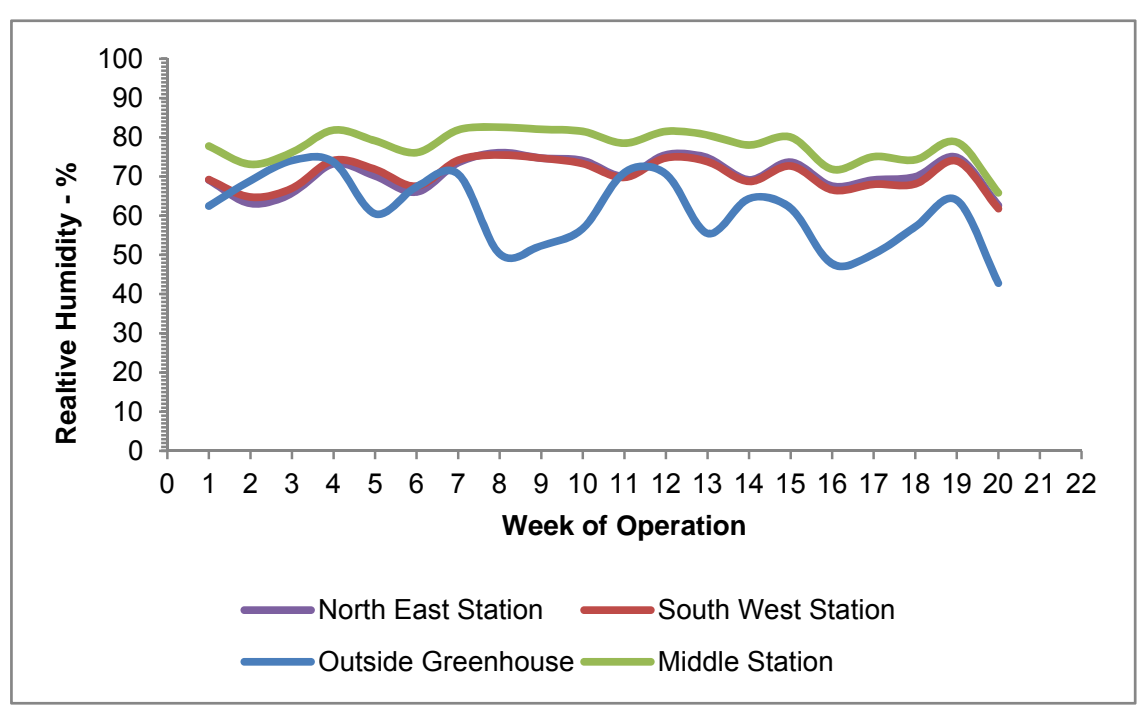

\begin{tabular}{|l|l|l|}
\hline 18 & $03 / 24 / 14$ & $03 / 30 / 14$ \\
\hline 19 & $03 / 31 / 14$ & $04 / 06 / 14$ \\
\hline 20 & $04 / 07 / 14$ & $04 / 13 / 14$ \\
\hline
\end{tabular}

Figure 12b. Average relative humidity (Commercial Greenhouse).

Figures 13 and 14 show comparisons of the weekly, average daily GS3 soil sensor measurements. Pot media temperatures for ENT-3 were stable and level at approximately $20^{\circ} \mathrm{C}$ throughout the entire 20 -week production period (Figure 13a). However, ENT-3 roots were $3-4{ }^{\circ} \mathrm{C}$ warmer than the commercial house, where medium temperatures varied between 13 and $20^{\circ} \mathrm{C}$ (Figure 13b). The cooperator house roots were especially cold at $13-14{ }^{\circ} \mathrm{C}$ versus $20^{\circ} \mathrm{C}$ at ENT-3 during weeks 6-11, (January 2014). These temperature differences were probably due to the differences in the heating distribution systems of the two houses.

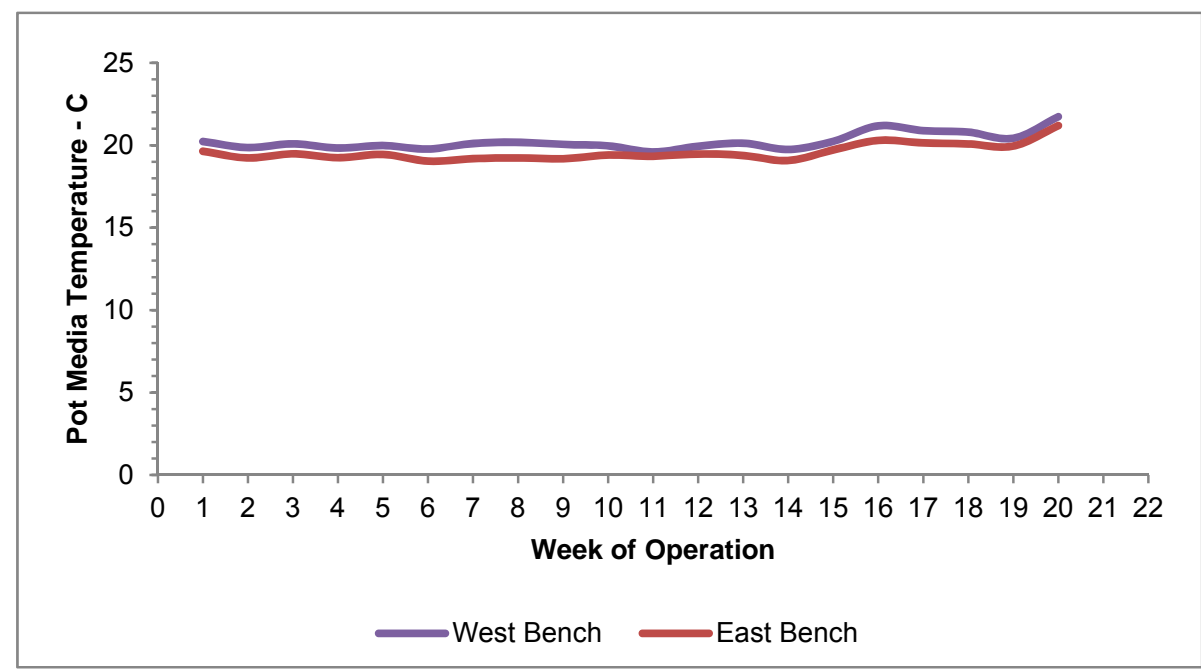

Figure 13a. Average weekly pot media temperatures (UNL-ENT-3).

\begin{tabular}{|c|c|c|}
\hline Week & \multicolumn{2}{|c|}{ Date Range } \\
\hline 1 & $11 / 25 / 13$ & $12 / 01 / 13$ \\
\hline 2 & $12 / 02 / 13$ & $12 / 08 / 13$ \\
\hline 3 & $12 / 09 / 13$ & $12 / 15 / 13$ \\
\hline 4 & $12 / 16 / 13$ & $12 / 22 / 13$ \\
\hline 5 & $12 / 23 / 13$ & $12 / 29 / 13$ \\
\hline 6 & $12 / 30 / 13$ & $01 / 05 / 14$ \\
\hline 7 & $01 / 06 / 14$ & $01 / 12 / 14$ \\
\hline 8 & $01 / 13 / 14$ & $01 / 19 / 14$ \\
\hline 9 & $01 / 20 / 14$ & $01 / 26 / 14$ \\
\hline 10 & $01 / 27 / 14$ & $02 / 02 / 14$ \\
\hline 11 & $02 / 03 / 14$ & $02 / 09 / 14$ \\
\hline 12 & $02 / 10 / 14$ & $02 / 16 / 14$ \\
\hline 13 & $02 / 17 / 14$ & $02 / 23 / 14$ \\
\hline 14 & $02 / 24 / 14$ & $03 / 02 / 14$ \\
\hline
\end{tabular}




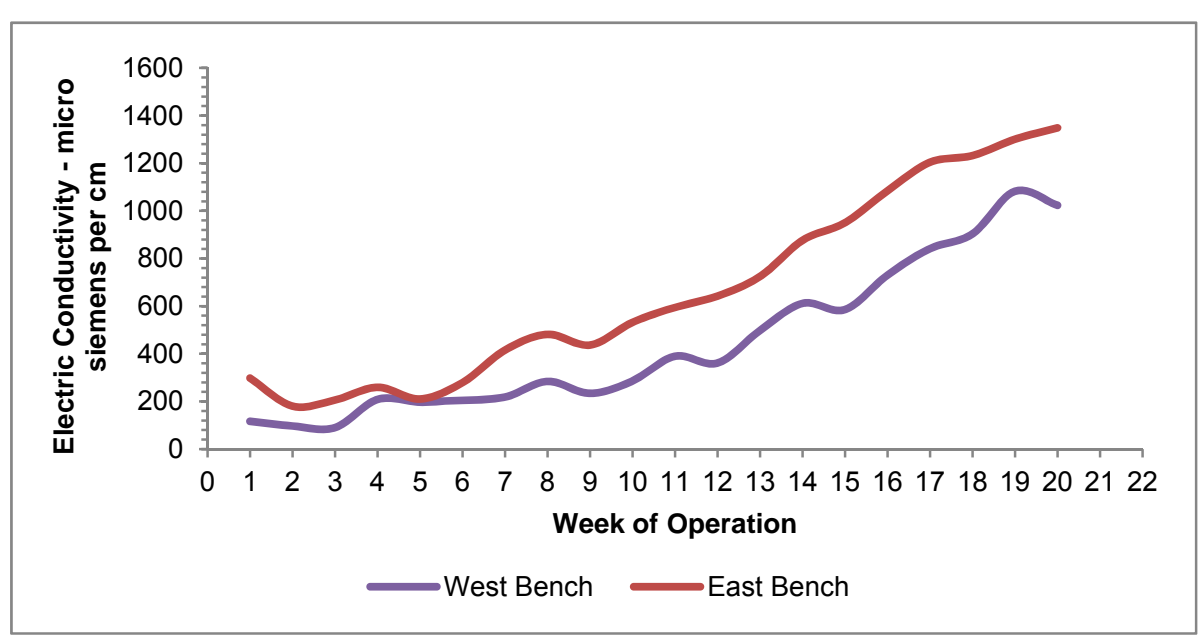

\begin{tabular}{|l|l|l|}
\hline 15 & $03 / 03 / 14$ & $03 / 09 / 14$ \\
\hline 16 & $03 / 10 / 14$ & $03 / 16 / 14$ \\
\hline 17 & $03 / 17 / 14$ & $03 / 23 / 14$ \\
\hline 18 & $03 / 24 / 14$ & $03 / 30 / 14$ \\
\hline 19 & $03 / 31 / 14$ & $04 / 06 / 14$ \\
\hline 20 & $04 / 07 / 14$ & $04 / 13 / 14$ \\
\hline
\end{tabular}

Figure 13b. Average weekly electrical conductivities (UNL-ENT-3).

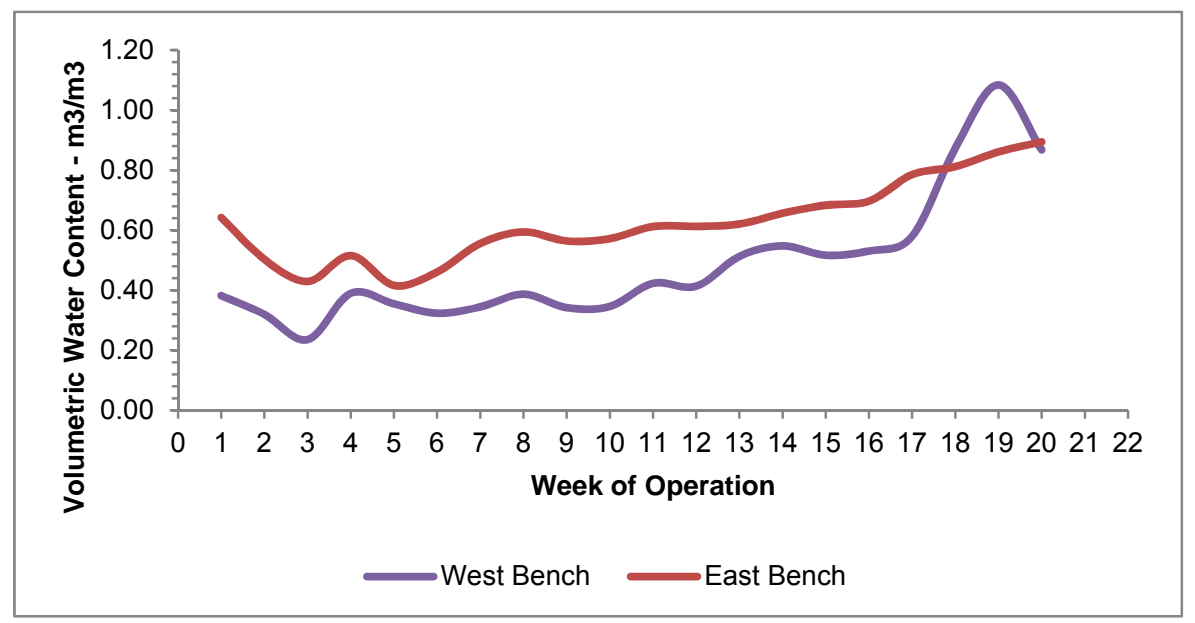

Figure 13c. Average weekly pot media volumetric water contents (UNL-ENT-3).

EC is a measure of the fertilizer salts available to the plant. EC's tended to increase as the crops grew and flowered because there was an increase in fertilizer application in order to meet the nutritional needs of the crop (Figures 13b and 14b). EC's started at around 100 micro Siemens per $\mathrm{cm}$ at week one to around 1000 micro Siemens per $\mathrm{cm}$ at the $20^{\text {th }}$ week for ENT-3. EC was consistently 200 micro Siemens per $\mathrm{cm}$ higher for pots on the East bench of ENT-3 compared to the west bench (Figure 13b).

EC's were started at around 100 micro Siemens per $\mathrm{cm}$ at week one to around 200 to 800 micro Siemens per $\mathrm{cm}$ at the $20^{\text {th }}$ week for the cooperator house, but with a lot of variability over the 20 -week period. Sensors in the middle bench of the commercial house indicated the middle bench consistently had less fertilizer available in the mix. The NE and SW sensors indicated similar fertilizer levels until around January when the NE area had more fertilizer in the mix than the SW area (Figure 14b).

In ENT-3, volumetric water contents tended to follow a similar pattern as the EC for the flag pots (Figure 13c). Volumetric water contents tended to drop between weeks 1 and 7, but were above 40 percent thereafter.

At the commercial house, volumetric water content for the flag pots varied greatly with the SW bench usually receiving and retaining more water than the pots at the NE position or even the pots located on the middle bench at the middle of the house (Figure 14c).

The CapMat appeared to perform quite differently in the cooperator house versus ENT-3. Downstream pots in the cooperator house were apparently drier and thus not providing as much fertilizer. It is not clear at this point, whether factors such as water distribution, cultivar usage differences, insect predation, or disturbed root attachment to the capillary mat fabric had any bearing on the performance. 


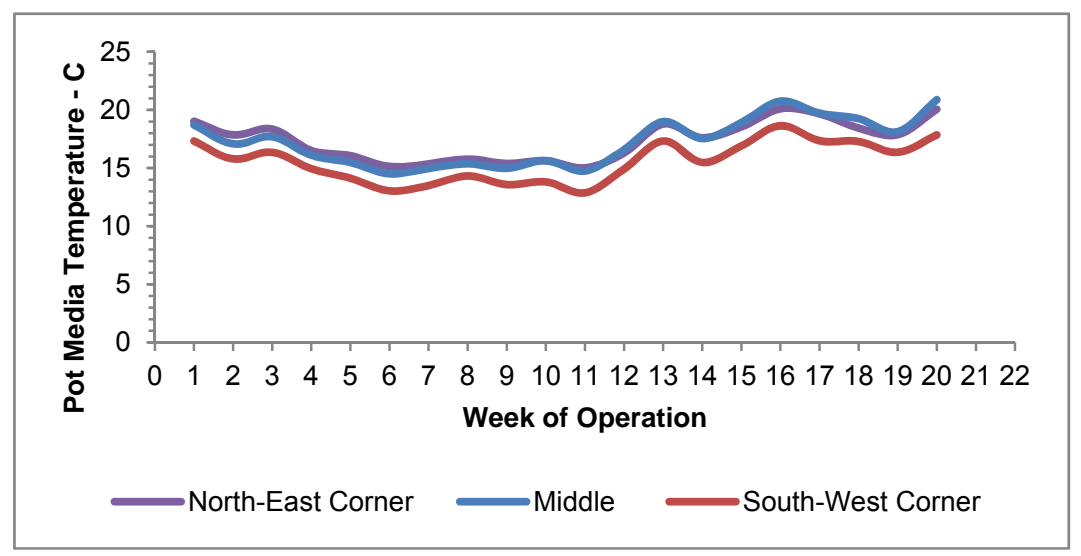

Figure 14a. Average weekly pot medium temperatures (Commercial greenhouse).

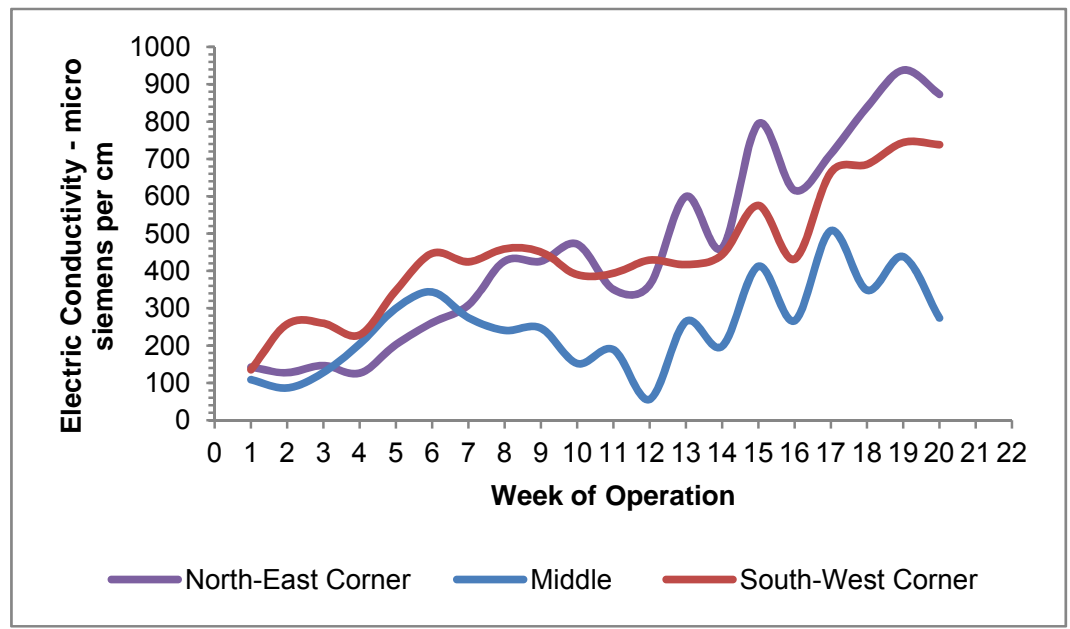

Figure 14b. Average weekly electrical conductivities (Commercial greenhouse).

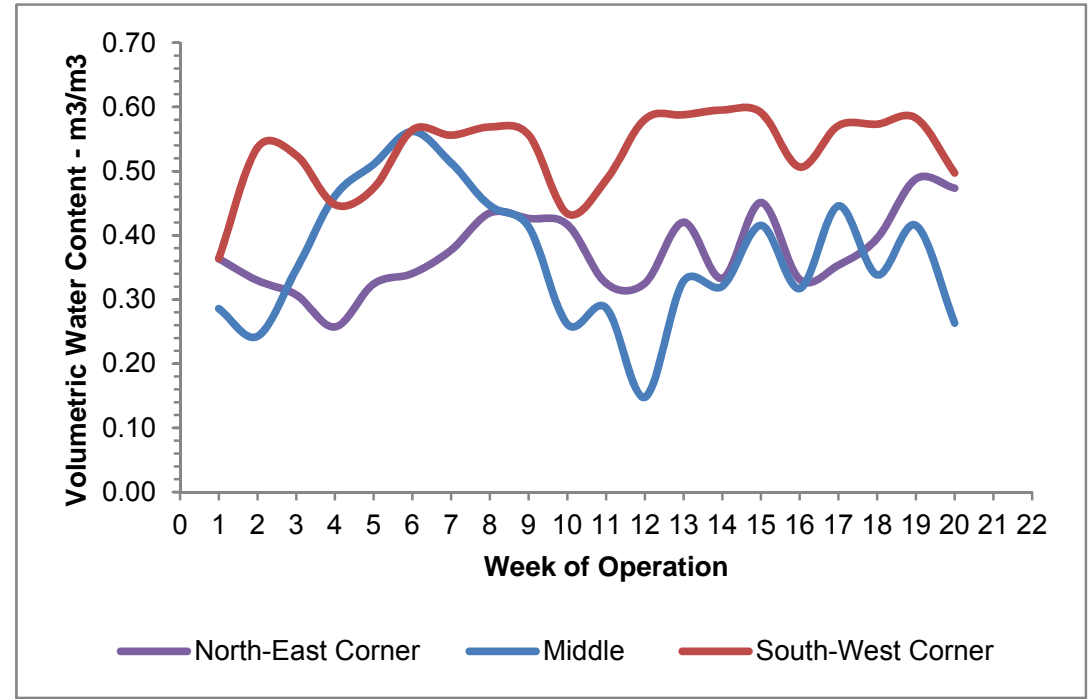

\begin{tabular}{|c|c|r|}
\hline Week & \multicolumn{2}{|c|}{ Date Range } \\
\hline 1 & $11 / 25 / 13$ & $12 / 01 / 13$ \\
\hline 2 & $12 / 02 / 13$ & $12 / 08 / 13$ \\
\hline 3 & $12 / 09 / 13$ & $12 / 15 / 13$ \\
\hline 4 & $12 / 16 / 13$ & $12 / 22 / 13$ \\
\hline 5 & $12 / 23 / 13$ & $12 / 29 / 13$ \\
\hline 6 & $12 / 30 / 13$ & $01 / 05 / 14$ \\
\hline 7 & $01 / 06 / 14$ & $01 / 12 / 14$ \\
\hline 8 & $01 / 13 / 14$ & $01 / 19 / 14$ \\
\hline 9 & $01 / 20 / 14$ & $01 / 26 / 14$ \\
\hline 10 & $01 / 27 / 14$ & $02 / 02 / 14$ \\
\hline 11 & $02 / 03 / 14$ & $02 / 09 / 14$ \\
\hline 12 & $02 / 10 / 14$ & $02 / 16 / 14$ \\
\hline 13 & $02 / 17 / 14$ & $02 / 23 / 14$ \\
\hline 14 & $02 / 24 / 14$ & $03 / 02 / 14$ \\
\hline 15 & $03 / 03 / 14$ & $03 / 09 / 14$ \\
\hline 16 & $03 / 10 / 14$ & $03 / 16 / 14$ \\
\hline 17 & $03 / 17 / 14$ & $03 / 23 / 14$ \\
\hline 18 & $03 / 24 / 14$ & $03 / 30 / 14$ \\
\hline 19 & $03 / 31 / 14$ & $04 / 06 / 14$ \\
\hline 20 & $04 / 07 / 14$ & $04 / 13 / 14$ \\
\hline & & \\
\hline
\end{tabular}

Figure 14c. Average weekly pot media volumetric water contents (Commercial greenhouse). 
In terms of plant survival, the percentage of plants that survived and produced in the commercial house was higher than in the UNL research greenhouse, 98\% versus $87 \%$ (Table 3 ). In terms of strawberry fruit production, the UNL greenhouse plants produced more pounds per plant for both the Fall-Winter and WinterSpring growth periods. Plant cultivars Evie-2 and Evie-2+ produced more saleable fruit than Seascape or Seascape+ for both locations. Cultivar San Andreas, which is a newly available cultivar, did poorly during the Fall-Winter period, but produced a good crop during the Winter-Spring period.

Table 3. Comparison of Strawberry Production for University of Nebraska Research Greenhouse (ENT-3) versus Commercial Grower Production (2013-2014) ${ }^{1}$.

\begin{tabular}{|c|c|c|c|c|c|}
\hline \multirow[t]{2}{*}{ Harvest Period } & \multicolumn{5}{|c|}{ Strawberry Cultivars } \\
\hline & 'Evie-2' & 'Evie-2' + & $\begin{array}{c}\text { 'San } \\
\text { Andreas' }\end{array}$ & 'Seascape' & 'Seascape' + \\
\hline \multicolumn{6}{|c|}{ Pounds per plant per cultivar (grams per plant) } \\
\hline \multicolumn{6}{|c|}{ University of Nebraska - ENT-3 } \\
\hline $\begin{array}{l}\text { October - December } \\
31\end{array}$ & $0.189(85.7)$ & $0.212(96.2)$ & $0.096(43.5)$ & $0.053(24.0)$ & $0.175(79.4)$ \\
\hline January - April 12 & $1.141(517.6)$ & $1.296(587.9)$ & $0.924(419.1)$ & 0.955 (433.2) & $0.984(446.3)$ \\
\hline Number of live plants & 47 & 47 & 47 & 40 & 28 \\
\hline \multicolumn{6}{|l|}{209 plants out of 240} \\
\hline \multicolumn{6}{|c|}{ Commercial Greenhouse - Dwight, NE } \\
\hline $\begin{array}{l}\text { October - December } \\
31\end{array}$ & $0.204(92.5)$ & $0.280(127.0)$ & $0.082(37.2)$ & $0.094(42.6)$ & $0.168(76.2)$ \\
\hline January - April 12 & $0.846(383.7)$ & $0.797(361.5)$ & $0.565(256.3)$ & 0.793 (359.7) & $0.773(350.6)$ \\
\hline Number of live plants & 240 & 250 & 105 & 224 & 217 \\
\hline 1036 plants out of 105 & & & & & \\
\hline
\end{tabular}

${ }^{1}$ The goal was to select cultivars that would produce approx. 1 pound $(453.6 \mathrm{~g})$ of berries per plant. Plant names with a "+" were select crowns that had a larger more extensive root system and a higher per plant purchase price.

\section{Conclusions}

Soilless media sensors gave reliable readings of moisture content and agreed with visual observations of plant stress. The increased light transmittance in the cooperator house was probably due to the new special double poly cover. This higher transmittance did translate to similar or higher berry production for the Fall-Winter period when the plants were smaller. However once the plants grew larger, the UNL greenhouse plants out produced the cooperator house plants. This could be due to the possibility that plants were grown at different densities per bench. As such, the commercial house was planted on typical spacing of $1 \mathrm{ft} .{ }^{2}\left(0.093 \mathrm{~m}^{2}\right)$ while plants at the UNL house were on $1.3 \mathrm{ft}^{2}\left(0.12 \mathrm{~m}^{2}\right)$. Thus, the plants at the UNL greenhouse may have benefited from more PAR off the reflective white mulch than the closer spaced plants in the commercial 
cooperator's house. However, this is not a certainty due to the fluctuations in the water/fertilizer levels (as measured by the GS-3 sensor, the lack of consistent root medium temperatures, and the fluctuations in the air temperatures due to the different heating system in the commercial house.

\section{References Cited}

1. Burnett, S., G.E. Meyer, M. Van lersal, and R. Hanson, 2012. Save Water with Automation and Sensors. Greenhouse Grower, July: pp 1-3.

2. Durner, E.F. 1999. Winter greenhouse strawberry production using conditioned plug plants. HortScience 34:615-616.

3. Garland, K., S.E. Burnett, M. Day, and M.W. van lersel. 2012. Influence of substrate water content and daily light integral on photosynthesis, water use efficiency, and morphology of Heuchera americana. J. Amer. Soc. Hort. Sci. 137:57-67.

4. Hancock, J.F. 2000. Strawberries. Springer Netherlands, pp445-455).

5. Hoagland, L.A, L. Hodges, G.A. Helmers, J.R. Brandle, and C.A. Francis, 2008. Does the Corn/Soybean farmer have time for Alternative crops? Hortcience 43(4):1228.

6. Hubbard, K.G., N. J. Rosenberg, and D. C. Nielsen, 1983. Automated Weather Data Network for Agriculture. J. Water Resources Planning and Management, 109(3):213-222.

7. Liu, J., W.R. Leatherwood and N.S. Mattson. 2012. Irrigation method and fertilizer concentration differentially alter growth of vegetable transplants. HortTechnology 22:56-63.

8. Mabie, D, G.E. Meyer, and S. Adams, 2013. Economic and Environmental Sustainability of Small Nebraska Greenhouse Systems, ASABE Paper Number 131608408. The American Society of Agricultural and Biological Engineering, St Joseph MI.

9. Meyer, G.E., D. Mabie, F.J. Hay, S. Adams, T. Bartels, and J.B. Fitzgerald, 2009. Improved Instrumentation and Controls for Biomass Heating and Impact on Greenhouse Profitability. ASABE Paper Number 09-096884. The American Society of Agricultural and Biological Engineering, St Joseph, MI.

10. Meyer, G.E., E.T. Paparozzi, E.A. Walter-Shea, E.E. Blankenship, and S.A. Adams, 2012. An investigation of reflective mulches for use over capillary mat systems for winter-time greenhouse strawberry production. Engineering in Agriculture 28(2):271-279.

11. Paranjpe, A.V., D.J. Cantliffe, E.M. Lamb, P'J. Stoffella, and C. Powell, 2003. Winter Strawberry Production in Greenhouses using Soilless Substrates: An Alternative to Methyl Bromide Soil Fumigation. Proc. Fla. State Hort Soc. 116:98-105.

12. Paparozzi, E.T., 2013. The Challenges of Growing Strawberries in the Greenhouse. HortTechnology 23(6): 800-802.

13. Paparozzi, E.T., G.E. Meyer, 2012. The return of capillary mats. Greenhouse Grower, August: 78-84.

14. Paparozzi, E.T., G.E. Meyer, M.E. Conley, S.A. Adams, E. E. Blankenship, P. E. Read, and V.L. Schlegel. 2011. Cultivar choice affects quality and production of winter grown strawberries. HortScience 46 supplement.-http://ashs.org/db/horttalks/detail.lasso?id=116120.

15. SDI-12 Support Group. http://www.sdi-12.org/

16. Wang, S. Y., J.A. Bunce, and J.L. Maas, 2003. Elevated carbon dioxide increases content of antioxidant compound in field-grown strawberries. Journal of Agricultural and Food Chemistry 52:4315-4320. 